\title{
The Pedagogical College at the Jagiellonian University (1921-1952): Origins, Founders, Significance
}

\begin{abstract}
The establishment and the activities of the Pedagogical College at the Jagiellonian University was an important event in the history of Polish pedagogy because this fact accelerated the process of its developing as a standalone academic discipline, with Krakow becoming an important centre of pedagogical thought. The process of developing an appropriate curriculum for training secondary school teachers, which combined practice and theory, took place in this College. In 1926, the Pedagogical College opened a Department of Pedagogy and saw the launch of the first Master's programme in pedagogy.
\end{abstract}

Keywords: pedagogy, teacher training, Jagiellonian University, Pedagogical College, Department of Pedagogy.

\section{Studium Pedagogiczne Uniwersytetu Jagiellońskiego (1921-1952): geneza, twórcy, znaczenie}

\begin{abstract}
Abstrakt
Utworzenie, a następnie działalność Studium Pedagogicznego Uniwersytetu Jagiellońskiego, stanowią ważne wydarzenie $\mathrm{w}$ dziejach polskiej pedagogiki, przyspieszyły bowiem proces jej kształtowania się jako samodzielnej dyscypliny naukowej, a Kraków dzięki temu stał się ważnym ośrodkiem badań naukowych w tym zakresie. W Studium wypracowano model kształcenia nauczycieli szkół średnich harmonijnie łączący praktykę z teorią. Przy Studium w roku 1926 utworzono Katedrę Pedagogiki oraz uruchomiono magisterskie studia pedagogiczne.
\end{abstract}

Słowa kluczowe: pedagogika, kształcenie nauczycieli, Uniwersytet Jagielloński, Studium Pedagogiczne, Katedra Pedagogiki.

\footnotetext{
* Pedagogical University of Krakow.

Article Received: January 16, 2020; Accepted: May 25, 2020.
} 


\section{Introduction}

The Pedagogical College of the Jagiellonian University, created in the mid-1920s, played a significant role in the development of Polish pedagogy, accelerating the institutionalization process and promoting the development of scientific research. Pedagogy began to be practised as an independent scientific discipline, and moreover, thanks to the activities of the College, it was possible to develop and implement a full pedagogical study programme.

The history of the Krakow College has already been the subject of several publications (Baścik 1967; Dutkowa 1968; Perkowska 1995; Michalewska 1996; Dybiec 2000; Dormus 2019), so the purpose of this article is not to present its history once more, but to focus on a few less exposed themes such as its origin and the characters of its creators.

Interest in pedagogy in the university environment was influenced by the necessity of solving the problem of educating secondary school teachers, providing them with appropriate practical and theoretical vocational training, which became more apparent in the 19th century. The process of the formation of Krakow pedagogy was the result of a combination of local traditions and Western European influences, especially German ones.

\section{The beginnings of university teacher education in Krakow}

Krakow had its own traditions of teaching secondary school teachers dating back to the times of the Commission of National Education. For the Commission, the issue of teacher education was one of the most important problems to be resolved. An undoubted merit of the Commission was the consideration of teachers within the uniform state regulations, including defining a path to the profession leading through university studies for the emerging category of lay teachers (Szybiak 2008: 16-17).

It was then, as a result of the reform undertaken by Hugo Kołłątaj, that the Szkoła Główna Koronna (Principal School of the Realm, later Jagiellonian University), began operating a Teachers' Seminary headed by Antoni Popławski, from the academic year 1780/1781. The candidates selected by the academic assemblies were to prepare practically in schools under the supervision of professors over two years, and then study in the seminary for three years, before returning to the home school (Kurdybacha, Mitera-Dobrowolska 1973: 226-227).

These studies, however, did not provide a good preparation for school work and did not give specialization in many subjects (Dutkowa 1973: 58). Based on the models of the Piarist congregation, Popławski's seminary was reorganized in 1783 in the spirit of Kołłątaj's ideas. From now on, the trainee teachers were no longer to live in college as boarders, but in dormitories or houses where they gave private 
lessons to gain teaching practice. Candidates were sent to their studies by faculty assemblies or went of their own will. After the entrance examination and passing the one-year trial period, they were allowed to continue their studies on the condition of making a submission. They had to participate in lectures and weekly events reminiscent of today's seminars, at which they were required to deliver at least two papers a year. Every month they also held meetings under the guidance of a professor, at which they familiarized themselves with Commission Acts, new textbooks and teaching methods. The pedagogical practice was quite limited and consisted of conducting lessons as a substitute for sick teachers or performing the function of a guardian, i.e. a tutor and minder of school children. An undoubted advantage of this education system was the extensive schedule of classes and close supervision of the university over the candidates, as well as competitive exams that allowed the selection of the best candidates. However, there was a lack of regular school practice and wider inclusion of pedagogical theory. Over 100 candidates with teaching status (Kurdybacha, Mitera-Dobrowolska 1973: 228, 230, 233-235) emerged from the Krakow seminary in 1780-1793.

The activities of the Teachers' Seminary gave rise to the education of secondary school teachers in connection with a university. The partitions, however, put an end to its functioning. In the nineteenth century, one had to look for other models - and the best ones were Prussian.

\section{Education of secondary school teachers in Galicia}

Johann Friedrich Herbart, considered to be the founder of scientific pedagogy, writing his "General Pedagogy" in 1806 was the first to justify the status of pedagogy as an independent scientific discipline. He was also the first to be habilitated in 1802 in the field of pedagogy, while in Königsberg he ran a teacher training seminary (Kot 1996: 154). However, it is not him, but Ernest Christian Trapp, a German teacher and theoretician associated with the philanthropist movement, who deserves the merit for having joined within a university one institution for the theoretical and practical education of future teachers. This was done as part of his seminary at the University of Halle in 1779-1783. It was also to Trapp's merit that he separated pedagogical from theological education by dividing the teaching seminary from the theological seminary in which it had originally functioned (Gündel 1892).

Gradually, along with the increase in the importance of secondary school education, and in accordance with governmental decisions on the need to raise teachers' qualifications, interest in pedagogy increased at German universities. New subjects began to be introduced into the study programme: psychology, pedagogy and detailed didactics, and a compulsory pedagogy exam was added to the philosophy faculty. However, no pedagogy departments were established, and 
philosophers usually lectured in this field. Still, the experiences of Trapp and Herbart meant that the first institutional forms of practising pedagogy - pedagogical seminaries - were created at German universities. They were led by Herbart's students. The first, combined with a school for practice, was founded in Jena in 1844 by Karl Volkmar Stoy. More were created in Szczecin, Leipzig, Heidelberg, Wrocław and Göttingen. They closely combined theoretical education at the university level with its practical application during secondary school classes. The acquired knowledge and skills were verified during observations at school and final exams before special committees (Baścik 1967: 407-408; Szmyd 2003: 67-68).

The example of Prussia, through Austria, strongly influenced Galicia. However, the development of a model of education harmoniously combining practice with theory and the recognition of an independent pedagogical position at the university was slow in coming about. In the pre-autonomous era, "German concepts for teacher education in the spirit of neohumanism, especially its bureaucratic formulation, without any foundation in the form of pedagogical reflection" exerted an influence on teacher education (Szybiak 2009: 178). In addition, in those times, it was characteristic for state administrators to impose lectures on universities and to combine pedagogy with theology.

At the university in Krakow, the first lecturer in pedagogy (1804-1809) was the professor of philosophy Michał Wacław Voigt. In the years 1833-1850 at the Faculty of Philosophy there was a strange creature called the Department of Religion, Pedagogy and Greek Language. Lectures on pedagogy were conducted there, and the lecturers were mainly priests. The level of these lectures was low and they were not very popular. After 1850, the philosopher Józef Kremer lectured on pedagogy (Dutkowa 1968: 445).

In the second half of the nineteenth century, the situation began to improve gradually. As Kazimierz Szmyd notes, pedagogy practised in Galicia joined "the bloodstream of this discipline in the entire German-speaking educational and pedagogical circle" (Szmyd 2003: 71). This resulted in a deepening of studies on pedagogical issues, an increase in the number of publications, and an increase in the level of lectures and examination requirements.

The other stimulus that influenced the development of pedagogy in Galicia was the Austrian state's education policy regarding teacher training. During the period of autonomy, teacher education was controlled by state regulations. In 1897, a ministerial decree was issued obliging secondary school teacher candidates to complete at least seven semesters of university studies, including at least five at the faculty of philosophy. They had to pass colloquia on philosophy, pedagogy, psychology, language of instruction and an exam in a certain group of subjects taught in schools, as well as completing a year of apprenticeship at school, ending with independent teaching. In 1911, these requirements were tightened by introducing, among others things, an extended trial year, meaning practice in 
school pedagogical seminars, i.e. teams of candidates preparing for the profession in a secondary school under the eye of its head teacher (Dutkowa 1968: 444).

In Krakow, Leon Kulczyński became an important figure in educating future teachers. After completing his studies in classical philology and philosophy at the Jagiellonian University, in 1872 he became an assistant teacher at St. Anne's Gymnasium in Krakow, and, in 1876, he received the title of secondary school teacher, "which meant one of the fastest careers in Galician education" (Dybiec 1998: 110).

In 1877, Kulczyński obtained a doctorate in philosophy, and three years later he was habilitated on the basis of the work The Education of a Secondary School Teacher. He was the first Polish assistant professor who was habilitated in pedagogy. In the 1880/81 academic year, he began giving lectures at the university, which then became regular. They were, probably for the first time, conducted in a systematic and thoughtful way. Students attended them willingly, despite the fact that they had to be paid for, while at the same time they had a choice of free classes run by two other associate professors - Maurycy Straszewski and Teofil Ziemba.

Kulczyński implemented his conception of teacher education consistently. As an experienced teacher at St. Anne's Gymnasium, and in 1887-1922 its headmaster, he appreciated the role of practice. In December 1889, with the support of the vicepresident of the National School Council, Michał Bobrzyński, his former school friend, he sought permission for students to be admitted to observe lessons at St. Anne's. These practices, approved by the ministry in 1897, became official and compulsory. Kulczyński also proposed the creation of practical pedagogical courses at the university in Krakow, following the German model. Despite gaining the consent of the Philosophy Faculty Council, these courses did not materialise. From 1892, however, there were one-year practical courses run by Kulczyński at St. Anne's (Dutkowa 1968: 445; Olszewski 1971: 140-141; Dybiec 1998: 111). Kulczyński was also the author of the textbook Praktyczny kurs szkolenia nauczycieli w szkołach średnich (A Practical Course Training Teachers in Secondary Schools (Lviv 1906).

In the years 1913-1925, Kulczyński was the supervisor of the Jagiellonian University Pedagogical Circle, which independently conducted scientific work and popularized the pedagogical sciences. Outstanding scientists such as Józef Pieter and Adolf Molak (Olszewski 1971: 140-141; Dybiec 2000: 332-333) grew out of this environment.

However, Kulczyński's actions did not satisfactorily solve the issue of teacher education. The problem of the insufficient pedagogical preparation of trainee teachers, especially in the field of pedagogical theory and didactics, was constantly raised. The university did not create sufficient opportunities for a good understanding of pedagogical issues. It was also difficult for trainee teachers to learn from older colleagues who also lacked a theoretical background. With 
increasing anxiety, unpleasant results were found. "The severity of the problem was recognized as it is today - by observing the lowering of the level of secondary school graduates, which in turn directly hindered the implementation of the university programme" (Pacławska, Historia Studium Pedagogicznego UJ).

The lack of a scientific centre for the development of the pedagogical sciences became more and more severe. In Krakow, the idea of creating a chair of pedagogy had been growing since 1875 . For a long time, it failed to materialize due to the reluctant attitude of state authorities and the lack of appropriate staff. As the efforts to create the chair were unsuccessful, attempts were made to tackle the problem in various ways, including, in 1914, planning the introduction of didactic classes; in 1916, establishing a permanent pedagogical commission at the Faculty of Philosophy to develop study reform; and, finally, the introduction a year later of a two-year series of didactic classes relating to each of the major subjects taught in secondary school (Baścik 1967: 408-415; Dutkowa 1968: 445-447; Michalewska 1996: 57-58).

These activities were accompanied by a wider discussion. The most important contribution to it was that of Jan Władysław Dawid, in 1913, in the Pedagogical Movement. Dawid presented the project of establishing the Polish Pedagogical Institute in Krakow, a "special institution dedicated to scientific pedagogy and professional teacher education, an institution of a high scientific character", similar to institutions operating in Leipzig, Brussels, Geneva and St. Petersburg (Dawid 1961: 151). The institute was also to be "a centre from which impacts would generally emerge, which would contribute to awakening and enlightening the pedagogical awareness of the general public, spreading new achievements in this field, criticism of existing devices and methods, and initiatives for reform" (Dawid 1961: 152). From 1913, there was a Society of the Pedagogical Institute in Krakow established to implement this project (Michalski 1994: 23).

In the pre-war period, it was not possible to create in Krakow, as had been done in Lviv1, an independent pedagogical organizational structure. Despite this, both universities played a huge role in the pre-independence period in educating secondary school teaching staff and educators who could work in school administration. They were the only institutions of this type in Poland. Graduates of these universities took up work in Galician gymnasiums, and after 1905 in private schools in the Kingdom of Poland. "The legacy of the other two partitions - as Renata Dutkowa notes - was extremely poor in this respect" (Dutkowa 1968: 447).

\footnotetext{
1 A pedagogical seminary led by Bolesław Mańkowski operated at the University of Lviv in 1907-1921. It was an independent scientific and didactic institution preparing students of the philosophical and theological faculties for the teaching profession. Observation and teaching practice in secondary and primary schools were important elements of the education process conducted there (Szmyd 2003: 153-155).
} 


\section{Establishment and beginnings of the Pedagogical College of the Jagiellonian University}

After regaining independence, the number of secondary schools began to increase. This caused a demand for properly prepared teachers, and they were lacking. Only every fifth teacher had completed full university studies. The Ministry of Religious Denominations and Public Education (MWRiOP) tried to solve the situation by organizing a number of courses for teachers. In 1918, the State Pedagogical Institute and the Pedagogical Faculty of the Free Polish University, which was the first institution in the reborn Poland to systematically educate secondary school teachers, were established in Warsaw (Dutkowa 1968: 448). In 1922, the Free University established a chair of pedagogy (Chodakowska 1994: 151). Earlier, in the winter of 1919, the first Department of Pedagogy in independent Poland, headed by Antoni Danysz, had started operating at the university in Poznań. (Czubiński 1972). In Poznań, in accordance with the tradition of German universities, pedagogical sciences were included in the Faculty of Philosophy. This department was, unfortunately, liquidated by ministerial decision in 1933, as part of budget cuts (Chodakowska 1994: 164-165).

In Krakow, efforts were also made to give pedagogy institutional structures. Like the other European centres, the Jagiellonian University was in favour of establishing a separate pedagogical institute as a centre of education and research (Chodakowska 1994: 152). Władysław Heinrich showed great activity in this field.

Heinrich's scientific path is extremely interesting. His interests developed in two directions: the sciences, and psychology and the history of philosophy. He studied the sciences at the Zurich Technical University (1889-1891), and philosophy and psychology in Munich (1891-1893). He received his doctorate, written under the direction of Richard Avenarius, one of the creators of empirical criticism, in Switzerland in 1894. After returning to the country, Heinrich got employed as an assistant in the Department of Experimental Physics of the Jagiellonian University, led by August Witkowski. Thanks to Witkowski's understanding, he conducted pioneering research and experiments on sensory impressions. In 1903/1904 he co-founded the Experimental Psychology Laboratory 2.

The following years brought Heinrich's habilitation (1900) and professorship (1905). He went to France, England and the United States many times on scientific purposes. In 1911, he became the Chair of Philosophy at the Jagiellonian University after Father Stanisław Pawlicki (Gawecki 1960: 349-350; Rzepa, Dobroczyński 2009: 100-102). In his research, he focused on psychology and the history of philosophy. His orbit of interest also included issues related to pedagogy - but

\footnotetext{
2 There is a dispute over whether it was the first institution of its kind in Poland or whether priority should be given to the University of Lviv and Kazimierz Twardowski (Stachowski 2004: 258-260).
} 
more in terms of practical activities than scientific interests. In the field of pedagogy, he did not conduct his own research, focusing on organizational work. As Włodzimierz Szewczuk, a student of Heinrich, notes, the professor "perfectly understood the huge social significance of pedagogical sciences and, therefore, he paid special attention to raising the level of these sciences, especially their research facilities" (Szewczuk 1972: 19). In 1928, at the initiative of Heinrich, the Scientific Pedagogical Society was established, which was a serious centre of pedagogical thought in Poland (Szewczuk 1972: 19). Earlier, however, a Pedagogical College, headed by Heinrich, had been established at the university.

The College was to become the nucleus of a future independent institution conducting activities in the field of pedagogical practice and theory. The College took on that form because it worked well at the university in Krakow. As part of it, pharmacy, agricultural sciences and physical education developed successfully (Chodakowska 1994: 160).

The opening of the College on November 6, 1921 had a solemn character, it was attended by the prime minister and minister of education, Antoni Ponikowski. During the ceremony, Władysław Heinrich ${ }^{3}$, appointed as head of the College, said: "The College will teach how to educate young people so that they must reconcile their individual affairs and interests with the interests of the state and the whole of society" (Pacławska, Historia Studium Pedagogicznego Uf).

Heinrich took his activities in the college very seriously. "He worked on the thorough education in reliable knowledge of the students of philosophy, psychology and pedagogy entrusted to his care. He always set high and hard requirements, fought against all sterility, speculation and dilettantism - then he could be an enemy, he valued talent, independence, courage of opinion and diligence. Then he was a friend. (...). This brought him many enemies, but at the same time allowed him to raise a large number of talented students (...)" (Szewczuk 1972: 27).

Bolesław Gawecki, a student of the professor, stated, however, that Heinrich "belonged to the type of strong people who go their own way and are not willing to compromise or bend to the circumstances. He was impulsive, explosive, which sometimes put off those who judge at first sight, but he wished people well and his nature was thoroughly true, noble" (Gawecki 1958: 5).

Until 1930, the College was located in the building of the Male Teachers' Seminary at 22, Straszewski Street, and then in rooms rented from the PAU at 27, Straszewski Street. Plans for the construction of a new building were not implemented. For a long time, all administrative matters were handled by Heinrich himself, with the help of assistants, because the College had no office staff (Perkowska 1995: 60; Heinrich 1996: 33).

In addition to Professor Heinrich, two assistants worked in the College. Władysław Woelfle specialized in psychology and pedagogy, and expanded his

\footnotetext{
${ }^{3}$ Heinrich served as director until 1951.
} 
knowledge at the William Stern Institute in Hamburg as a scholarship holder of the MWRiOP Pedagogical Commission (Miąso 2003: 140). Feliks Wnorowski, after the Second World War, translated Locke's Some Thoughts Concerning Education (Wrocław 1959) and prepared Rousseau's Emile (Wrocław 1955) for printing.

Heinrich, unlike most professors at the Faculty of Philosophy, wanted the College to be an autonomous scientific and didactic unit. Ultimately, a compromise, which found expression in the College Statute, approved by the ministry in July 1922, won out. The College had two tasks: educating secondary school teachers and conducting scientific activities. It was a branch of the Faculty of Philosophy, but had its own director elected by the Faculty Council and approved by the MWRiOP. It also had an opinion-giving, supervising and initiating body - the Pedagogical Study Commission, which, according to the statute, was to be formed by the faculty lecturers elected by the Faculty of Philosophy Council, but, in fact, were representatives of the Faculty, including Heinrich, Władysław Natanson, Kazimierz Nitsch, Stanisław Kot, Zygmunt Mysłakowski, Stefan Szuman, and Władysław Szafer (Dutkowa 1968: 449, 452).

Candidates who had completed their third or fourth year of university studies were admitted to the College. They could continue their studies while attending classes at the College. They only paid registration fees and exam fees. The course lasted one year, and the weekly schedule of classes was 40 hours. Practical classes took the form of observation in secondary schools, and at the end the candidate taught lessons independently. The course ended with an exam in general subjects. It was also necessary to obtain teaching specialization certificates (Dutkowa 1968: 458-459; Perkowska 1995: 60-61).

The graduates of the College had full qualifications for teaching in secondary school, and were prepared for the profession simultaneously with their educational qualification. They did not have to sit the teacher's exam. However, obtaining a secondary school teacher's diploma was only possible after one year of teaching. Graduation made it possible to obtain the position of a full-time teacher immediately, which was associated with a higher salary (Baścik 1967: 417; Michalewska 1996: 64). All this contributed to the popularity of the College. Its apogee occurred in 1925/26, when 411 people studied there (Dutkowa 1968: 459-460). In the years 1921-1939, about 4,500 students attended the College, of whom over half were women (Perkowska 1995: 61, 63).

The popularity of the College was also influenced by the dissolution of the State Pedagogical Institute in Warsaw in 1925. After that, universities became the only teacher training centres. From the point of view of the state, this was a beneficial solution because it was much cheaper to combine university studies with pedagogical studies within one institution. The time needed to obtain qualifications was also shorter because the last years of university studies were combined with pedagogical studies. 
The formula of the College was expanded in 1928 with the opening of two-year ministerial pedagogical courses educating teachers of pedagogical subjects for teacher training institutions. They were intended for university graduates with a comprehensive teaching exam or a Master's degree/doctorate, and were taken mainly by active teachers. The students were obliged to take all exams in the field of a Master's Degree in Pedagogy and the College programme as well as to write their Master's thesis. The ministerial course had a separate superior authority in the Supervisory Committee, which included Władysław Heinrich and Zygmunt Mysłakowski as well as the curator Tadeusz Kupczyński. The courses probably existed until 1934, when their programme was unified with the programme of the College (Baścik 1967: 423; Dutkowa 1968: 462-463; Chodakowska 1994: 164).

\section{Establishment of the Department of Pedagogy}

The College struggled constantly with staffing problems. Detailed didactics was taught by secondary school and university teachers, but completing the staff teaching general subjects was much more difficult. There was a lack of lecturers in subjects as basic as pedagogy and history of education. As a result, the idea of creating appropriate departments as part of the College, especially a department of pedagogy (Dutkowa 1968: 453), returned. The problem was its proper staffing. Kulczyński was already too advanced in age to take over the leadership of the department. Henrich saw the future head of the Department of Pedagogy in the person of Marian Falski. The university even granted Falski a scholarship abroad, on which he stayed in the years 1915-1917. After returning, however, he chose to work at the Ministry of Education, and his habilitation did not occur in Krakow (Dutkowa 1968: 453; Michalski 1994: 23; Pacławska 1996: 16; Michalewska 1996: 59).

With the help of the university, the Pedagogical Commission of the Ministry of Religious Denominations and Public Education came about, which, in 1922, proposed foreign scholarships in the field of pedagogical sciences. At that time, Henrich proposed Zygmunt Mysłakowski as a candidate for a future scholarship. Mysłakowski, like Heinrich, first studied natural sciences, then philosophy and psychology. While working as a teacher, he maintained scientific contacts with professors of the Faculty of Philosophy at the Jagiellonian University, especially Władysław Heinrich, who became the promoter of his doctoral dissertation. He defended his doctorate in philosophy in 1917.

In May 1922, Mysłakowski, thanks to the support of the Philosophy Department, obtained an annual scholarship from the French government. In January 1923, he was in Paris, where he managed to make personal contact with Henri Bergson. In 1924, he returned to Krakow, and the next year he was 
habilitated based on the work Rozwój naturalny i czynniki wychowawcze (Natural Development and Educational Factors). In 1925, he took over the function of supervisor of the Jagiellonian University Pedagogical Students Circle from Kulczyński. Thanks to his activities, the number of members of the Circle quickly increased from several to several dozen people. In 1926 he became the head of the Department of Pedagogy. He was soon appointed an associate professor.

Mysłakowski lectured in pedagogy and general didactics. He also gave monographic lectures on outstanding representatives of European pedagogical thought: John Dewey, Georg Kerschensteiner, Emil Durkheim, and Maria Montessori. As many as 300 pedagogy Master's degree graduates wrote works under his supervision, until 1962 (Terlecka 2000: 251-252).

Once Mysłakowski took over as head of the chair, the development of scientific pedagogy was significant, and Krakow became an important centre. Mysłakowski built pedagogy "as an autonomous science, but did so using natural, psychological, sociological and philosophical knowledge as well as observations and personal teaching experience accumulated over years of study (...)" (Terlecka 2000: 242). As Tadeusz W. Nowacki notes: "Due to the multifaceted approach, this pedagogy can be called holistic" (Nowacki 1990: 181). The research interests of the department focused on the social foundations of education, contemporary pedagogical trends, and didactic and pedeutological issues. Mysłakowski initiated team work around these questions, and the teams he created included research workers, teachers and social activists (Baścik 1967: 421, 425-426; Michalski 1994: 24-25, 31; Szmyd 1997: 13-14; Dybiec 2000 : 451; Terlecka 2000: 240-241).

Mysłakowski hired Feliks Wnorowski first. In 1936, Bogdan Chrzanowski, who had previously worked in the Department of Educational Psychology, arrived. Tadeusz Nowacki worked as a volunteer from 1937, and after a year Stanisław Skrzeszewski, later the post-war minister of education and foreign affairs, took his place. Skrzeszewski, who was already a doctor at the time, had previously worked at the Pedagogical Institute in Katowice (Michalski 1994: 26).

Heinrich was particularly interested in establishing a chair of psychology, because "he understood perfectly the importance of psychology for pedagogy and, therefore, expanded the former to the widest extent possible" (Szewczuk 1972: 20). When Stefan Szuman was habilitated in 1927, he was entrusted with managing the newly established Department of Educational Psychology.

It was not possible to create a chair of the history of education, although in the years 1920-1934 there was a Chair of Cultural History headed by Stanisław Kot, and as part of the research conducted in it, historical and educational issues were dealt with. For sociology of education, didactics and the theory of education and teaching in primary schools, no departments were created (Dutkowa 1968: 453-455). 


\section{Launch of Master's pedagogical studies}

The establishment of the departments of pedagogy and psychology enabled the launch of pedagogical studies educating pedagogy Masters from 1926/1927. The reform of the philosophical faculties in 1925 made it possible to organize the course of studies, and also introduce a Master's degree, which was also a professional degree completing university education. The Act on the system of education of 1932 maintained the principle of the pedagogical education of secondary school teachers, imposing on them the obligation to complete one-year of professional practice. In this way, the Jagiellonian University developed a full programme and method of implementing pedagogical studies. Additionally, the University of Warsaw, the University of Poznań and the Polish Free University also had fully organized pedagogical studies (Chodakowska 1994: 151-152).

This undoubted achievement was not fully utilized. This was because of the Second World War and the political changes that followed. Huge personal losses that affected the environment of Polish teachers meant that in the rebuilding of Poland after years of occupation, a lack of them was severely felt. Meanwhile, one of the most important goals of education policy was to introduce universal teaching and the elimination of illiteracy. The issue of training new teaching staff became urgent.

\section{Post-war fate of the Pedagogical College and its liquidation}

The Pedagogical College resumed its activity in 1945 functioning within the Faculty of Humanities. Still managed by Heinrich ${ }^{4}$ and his deputy Zenon Klemensiewicz, it continued its activity on pre-war principles. In the first post-war years, 1945-1947, it even expanded. The expansion included a Peadological Clinic, a Department of Adult Education and Culture, and a Department of Adult Pedagogy 5 (https://pedagogika.uj.edu.pl/zaklad-pedagogiki-spolecznej-i-andragogiki). This raised hopes for the transformation of the College into a pedagogy department in the near future.

At the request of Władysław Heinrich, from 17 to 19 December 1945, the Ministry of Education convened a conference on teacher education, which was

\footnotetext{
4 After the war, Heinrich again took the position of head of the Department of Philosophy and director of the Experimental Psychology Laboratory of the Jagiellonian University. He was a member of the PAU board and managed the Faculty of History and Philosophy. After the dissolution of the PAU, he refused to join the PAS. He died on June 30, 1957.

5 In 1951, both of these departments were combined into one called the Department of Pedagogy and Adult Education. When the Faculty of Philosophy and History was established in 1953, the department was closed and its employees were transferred to the Group of Departments of Psychology and Pedagogy. The following year, 1954, they created a separate Department of Culture and Adult Education transformed, in 1957, into a chair.
} 
attended by representatives of the three levels of general, secondary and higher education. It supported the idea of educating secondary school teachers at universities (Konferencja w sprawie kształcenia nauczycieli) (Conference on teacher education). However, as it soon turned out, the education policy of the new authorities assumed a different model of teacher education. From 1946, higher pedagogical schools were established to initially educate secondary school teachers, and later also those for primary schools. One such institution was established in Krakow, which influenced the way the College operated. This fact and the common practice of employing people without diplomas authorizing them to work in education caused attendance at the College to drop dramatically. There were also unfavourable changes in the scope of education plans and the curriculum. Although the decree on the organization of science and higher education issued in the autumn of 1947 approved the pre-war curriculum (Decree of October 28, 1947, Article 77), and Heinrich even managed to extend the programme of the College with lectures on English language teaching, as well as on anatomy and physiology of the nervous system, at the end of that year, the ministry made changes to study plans consisting in limiting the number of hours of lectures on detailed didactics from 5 to 3, or even 2 a week. This conflicted with the original programme of the College (Krukowski 1983: 140).

Until the 1950/51 academic year, the question of the pedagogical education of students in teaching faculties was not regulated, so a huge number of teachers went to work in schools without proper pedagogical preparation. This matter was regulated only by the Act on Higher Education and Academic Staff of December 1951, introducing two degrees of higher education: the first educating employees with the highest level of professional qualifications in a given profession and the second educating primarily researchers (Act of 15 December 1951, Article 22). From the 1951/1952 academic year, some faculties and fields of study were introduced to the first degree study plan as compulsory subjects, elements of pedagogical sciences and teaching methodology for individual subjects, and in the third year, two-week pedagogical practice. The organization of these classes was to be dealt with by the chair of pedagogy (Krukowski 1983: 143-144). Organizational changes were carried out at the Jagiellonian University in the curricula of all subjects included in the Faculty of Humanities, Mathematics and Natural Sciences, thus adapting the didactic programmes to the needs of individual faculties. In this arrangement, there was not enough space for the Pedagogical College. At the same time, the authorities of the PRL sought to weaken the Jagiellonian University. Within five years, beginning in 1949, further faculties and all independent studies - including the Pedagogical College - established in the interwar period had been liquidated. In relation to the Pedagogical College, it was decided to merge the departments created in its framework into collective departments, which became part of the Faculty of Philosophy and Social Sciences (Dutkowa 1968: 467; Pacławska 1996: 17-18; Michalewska 1996: 64-65). 
In 1955, a decision was taken to liquidate higher pedagogical schools operating in university centres, but this did not apply to Krakow. Thus, hope for a pedagogical faculty was again thwarted. However, institutes of pedagogy and psychology still operated at the university. Until 1952, pedagogical studies conducted according to the pre-war programme also survived. After a break, in the 1955/1956 academic year, these studies resumed, but as a five-year course (Terlecka 2000: 251-252).

Discussions about the university education of trainee teachers were revived in the 1980s. In autumn 1990, at the initiative of the then Vice-Rector of the Jagiellonian University, Professor Lucjan Suchanek, work began to create a Pedagogical College. The organization of the study was entrusted to $\mathrm{dr}$ hab. Kazimierz Pacławska from the Institute of Pedagogy. The College began its activity on October 1, 1991 (http://www.sp.uj.edu.pl/studium/historia).

\section{Conclusion}

The establishment of the Pedagogical College in Krakow is an important event in the history of Polish pedagogy, its institutionalization and its development as an independent scientific discipline. Thanks to it and the faculties created in connection with it, the Jagiellonian University became an important scientific centre in the field of pedagogy. Master's pedagogical studies were launched, a specialized scientific library and a therapeutic and educational outpatient clinic for difficult children, operating under Mysłakowski's direction, were established. The initiative of establishing the Pedagogical Institute in Katowice led by Szuman and the Scientific Pedagogical Society (Dutkowa 1968: 454, 467; Pacławska 1996: 17-18) came from the Krakow university environment. After the war, the College tried to maintain the tradition of educating secondary school teachers at universities, which was established in Polish educational practice, and which contributed to maintaining their high level of vocational preparation.

\section{References}

Baścik S. (1967) Dzieje pedagogiki w Uniwersytecie Jagiellońskim, "Zeszyty Naukowe Uniwersytetu Jagiellońskiego. Prace Historyczne”, 16: 406-435.

Chodakowska J. (1994) Uniwersytecki studia pedagogiczne, "Rozprawy z Dziejów Oświaty": 151-172.

Czubiński A. (1972) Dzieje Uniwersytetu Poznańskiego w latach 1918-1939 in: Dzieje Uniwersytetu im. Adama Mickiewicza 1919-1969, Z. Grot (ed.), Poznań, Wydawnictwo Naukowe Uniwersytetu im. A. Mickiewicza: 59-303. 
Dawid J. W. (1961) Polski Instytut Pedagogiczny in: Dawid J.W., Pisma pedagogiczne, oprac. R. Wroczyński, Wrocław, Zakład Narodowy im. Ossolińskich: 150-160.

Dormus K. (2019) The Beginnings of Institutionalization of Pedagogy in Cracow, "Przegląd Historyczno-Oświatowy", 1/2: 47-59.

Dutkowa R. (1973) Komisja Edukacji Narodowej. Zarys działalności, wybór materiałów źródłowych, Wrocław, Zakład Narodowy im. Ossolińskich.

Dutkowa R. (1968) Studium Pedagogiczne Uniwersytetu Jagiellońskiego 1921-1952. (Zarys działalności), "Przegląd Historyczno-Oświatowy", 4: 444-459.

Dybiec J. (1998) Leon Kulczyński in: W. Bobrowska-Nowak, D. Drynda (ed.), Słownik pedagogów polskich, Katowice, Wydawnictwo Uniwersytetu Śląskiego.

Dybiec J. (2000) Uniwersytet Jagielloński 1918-1939, Kraków, Nakładem Polskiej Akademii Umiejętności.

Gawecki B. J. (1958) Władysław Heinrich (1869-1957), "Ruch Filozoficzny”, 1-3: 2-10.

Gawecki B. J. (1960) Władysław Heinrich in: Polski Słownik Biograficzny, vol. IX, Wrocław 1960-1961, Zakład Narodowy im. Ossolińskich: 249-350.

Gündel A. (1892) Leben und Wirken Ernst Christian Trapp's, Leipzig.

Heinrich T. (1996) Wspomnienie o Ojcu - Władysławie Heinrichu in: Tradycja i wyzwania, Księga pamiątkowa na 75-lecie założenia Studium Pedagogicznego Uniwersytetu Jagiellońskiego 1921-1996, K. Pacławska (ed.), Kraków, Towarzystwo Autorów i Wydawców Prac Naukowych “Universitas”: 31-35.

Konferencja $w$ sprawie kształcenia nauczycieli odbyta $w$ Krakowie $w$ dniach 17, 18, 19 grudnia 1945 (1946), Warszawa, Wydawnictwo Naukowe Towarzystwa Pedagogicznego.

Kot S. (1996) Historia wychowania, vol. II, Warszawa, Wydawnictwo Akademickie "Żak".

Kronika Uniwersytetu Jagiellońskiego za lata 1926/27-1929/30, Kraków 1934.

Krukowski J. (1983) Kształcenie nauczycieli na poziomie wyższym in: Kształcenie nauczycieli w Polsce Ludowej 1945-1975, J. Jarowiecki, B. Nowecki, Z. Ruta (eds.), Kraków, Wydawnictwo Naukowe WSP: 137-269.

Kulczyński L. (1906) Praktyczny kurs szkolenia nauczycieli w szkołach średnich, Lwów (From "Muzeum"). 
Kurdybacha Ł., Mitera-Dobrowolska M. (1973) Komisja Edukacji Narodowej, Warszawa, PWN.

Miąso J. (2003) Komisja Pedagogiczna Ministerstwa Wyznań Religijnych i Oświecenia Publicznego (1921-1928) i jej rola w rozwoju nauk pedagogicznych, "Rozprawy z Dziejów Oświaty": 135-159.

Michalewska K. (1996) Studium Pedagogiczne UJ 1921-1952. Zarys dziejów i organizacja studiów in: Tradycja i wyzwania. Księga pamiątkowa na 75-lecie założenia Studium Pedagogicznego Uniwersytetu Jagiellońskiego 1921-1996, K. Pacławska (ed.), Kraków, Towarzystwo Autorów i Wydawców Prac Naukowych “Universitas”: 55-69.

Michalski G. (1994) Zygmunt Mysłakowski (1890-1971). Działalność i twórczość pedagogiczna, "Acta Universitatis Lodziensis. Folia Paedagogica et Psychologia", vol. 33, Łódź, Wydawnictwo Uniwersytetu Łódzkiego.

Nowacki T. W. (1990) Zygmunt Mysłakowski - współtwórca pedagogiki naukowej. W setna rocznicę urodzin (1890-1971), "Przegląd Historyczno-Oświatowy”, 2: 159-185.

Olszewski K. (1971) Leon Kulczyński in: Polski Słownik Biograficzny, vol. XVI, Wrocław 1971, Zakład Narodowy im. Ossolińskich: 140-141.

Pacławska K. (1996) Wprowadzenie in: Tradycja i wyzwania. Księga pamiq̨tkowa na 75-lecie założenia Studium Pedagogicznego Uniwersytetu Jagiellońskiego 1921-1996, K. Pacławska (ed.), Kraków, Towarzystwo Autorów i Wydawców Prac Naukowych "Universitas": 15-19.

Perkowska U. (1995) Studia i kursy zawodowe na Uniwersytecie Jagiellońskim w latach 1868/69-1938/39, Kraków, Księgarnia Akademicka.

Rzepa T., Dobroczyński B. (2009) Historia polskiej myśli psychologicznej. Gałązki $z$ drzewa Psyche, Warszawa, Wydawnictwo Naukowe PWN.

Stachowski R. (2004) Historia współczesnej myśli pedagogicznej. Od Wundta do czasów najnowszych, Warszawa, Wydawnictwo Naukowe "Scholar".

Szewczuk W. (1972) Władysław Heinrich - filozof, psycholog, pedagog. (W stulecie urodzin), "Przegląd Psychologiczny" 1972, 1: 17-29.

Szmyd K. (2003) Twórcy nauk o wychowaniu w środowisku akademickim Lwowa (1860-1939), Rzeszów, Wydawnictwo Uniwersytetu Rzeszowskiego.

Szmyd K. (1997) Zygmunt Karol Mysłakowski (1890-1971). Twórczość i wkład do rozwoju nauk o wychowaniu, Rzeszów, Wydawnictwo Wyższej Szkoły Pedagogicznej. 
Szybiak I. (2008) Zawód nauczyciela a Komisja Edukacji Narodowej in: Dylematy historii i polityki. Księga dedykowana profesor Annie Magierskiej, R. Chwedoruk, D. Przastek (eds.), Warszawa, Oficyna Wydawnicza Aspra-JR: 15-22.

Szybiak I. (2009) Recenzja: Kazimierz. Szmyd, Twórcy nauk o wychowaniu w środowisku akademickim Lwowa (1860-1939), Rzeszów 2003, Wydawnictwo Uniwersytetu Rzeszowskiego, 434, “Rozprawy z Dziejów Oświaty”: 177-180.

Terlecka W. (2000) Zygmunt Karol Mysłakowski (1890-1971) in: Złota księga Wydziału Filozoficznego, J. Miklaszewska, J. Mizera (eds.), Kraków, Księgarnia Akademicka: 239-245.

\section{Online sources}

Dekret z dnia 28 października 1947 roku o organizacji nauki i szkolnictwa wyższego (Dz. U. z 1947 r., nr 66, poz. 415) http://prawo.sejm.gov.pl/isap.nsf/Doc Details.xsp?id=WDU19470660415; date accessed: 8.05.2020.

Pacławska K., Historia Studium Pedagogicznego UJ, http://www.sp.uj.edu.pl/ studium/historia; date accessed: 1.12.2019.

Ustawa z dnia 15 grudnia 1951 roku o szkolnictwie wyższym i pracownikach nauki (Dz.U. z 1952 r., nr 6, poz. 38) http://prawo.sejm.gov.pl/isap.nsf/DocDetails.xsp?id= WDU19520060038; date accessed: 9.05.2020.

https://pedagogika.uj.edu.pl/zaklad-pedagogiki-spolecznej-i-andragogiki; date accessed: 1.12.2019. 